Jpn. J. Med. Sci. Biol., 45, 113 - 125, 1992.

\title{
T-CELL HYBRIDOMAS RECOGNIZING THE ENVELOPE PROTEINS OF SEMLIKI FOREST VIRUS: THEIR SENSITIVITY TO ENDO/LYSOSOMAL PROTEASE AND THE ANTIGENICITY
}

\author{
Eiji WATARI and Kozo YOKOMURO
}

Department of Microbiology and Immunology, Nippon Medical School, 1-1-5 Sendagi,Bunkyo-ku, Tokyo 113

(Received May 18, 1992. Accepted June 17, 1992)

SUMMARY: Eight T-cell hybridomas were established from the draining lymph node of $\mathrm{C} 3 \mathrm{H}$ mice immunized with Semliki forest virus (SFV). Six of them showed specificity toward viral-structure protein E2, while the remaining two clones included one with specificity to an other structural protein E1 and the other with specificity to $\mathrm{C}$. The production of IL-2 by the E2 protein-specific T-cell hybridomas in the presence of SFV was suppressed by treating the antigenpresenting cells (APC) with ammonium chloride raising $\mathrm{pH}$ of the acidic compartments. It was found also that treatment of APC with a thiol protease inhibitor, leupeptin or E64, resulted in a reduced response of some of the E2specific T-cell hybridomas. The E2 protein of SFV proved to be resistant at $\mathrm{pH}$ 7.0 , and sensitive at pH 5.0 to in vitro cathepsin B treatment. In contrast, the $\mathrm{E} 1$ and $\mathrm{C}$ proteins proved to be resistant to both $\mathrm{pH}$ values. These results indicate that the thiol protease, probably cathepsin B, works as one of the enzymes group involved in antigen processing.

\section{INTRODUCTION}

Semliki forest virus (SFV), a virus of the alphavirus group, is characterized by a simple envelope. It has been extensively used as a model in research concerning the structure and assembly of the cellular membrane. The

渡理英二・横室公三 (日本医科大学微生物学免疫学教室 文京区千駄木1-1-5) 
envelope of this virus consists of the trans-membrane glycoproteins, E1 and E2、 and a bilayer associated with E3 protein (1).

Helper $\mathrm{T}$ cells are essential for the development of the virus-specific cytotoxic T-cell responses and the proliferation of the virus-specific B cells (2). For these functions, helper $\mathrm{T}$ cells recognize short paptides derived from the nominal antigen by proteolysis on APC in association with major histocompatibility complex (MHC)-encoded class $\Pi$ molecules (3).

SFV binds to the virus receptor on the cell membrane and is endocytosed. This process leads to the formation of uncoated vesicles and their fusion with other vesicles. It is known that the $\mathrm{pH}$ value in the endocytic compartments is lowered to 6.0 in the process of the endosome formation. At $\mathrm{pH} 6.0$, the viral envelope fuses with the endosome membrane through the $\mathrm{E} 1$ protein and the nucleocapsid is ejected into the cytoplasm, while the viral envelope protein remains in the endocytic compartments (1). It is considered that at the $\mathrm{pH}$ values allowing the fusion of the viral envelope with the endosome membrane, the E1 protein undergoes irreversible structural changes, an assumption supported by the fact that the $\mathrm{E} 1$ protein in the endosome becomes trypsin-resistant at this $\mathrm{pH}$ (4-6).

In the present study, we attempted to determine which SFV protein is the dominant immunogen for helper $\mathrm{T}$ cells. For this end, we established a number of $\mathrm{SFV}$-specific helper $\mathrm{T}$ cell hybridomas from the lymph node cells of SFVimmunized mice and then determined the specificity of each hybridoma to E1, E2 or C protein of SFV. We found that, among eight hybridomas obtained, six exhibited specificity to $\mathrm{E} 2$ protein and only two showed specificity to E1 or C protein. Since the treatment of purified SFV with cathepsin B at $\mathrm{pH} 5.0$ cleaved $\mathrm{E} 2$ protein, but not $\mathrm{E} 1$ or $\mathrm{C}$ protein, it was suggested that $\mathrm{E} 1$ and $\mathrm{C}$ proteins, but not E2 protein, were difficult to be processed to immunogenic short peptides in endosomes of APC.

\section{MATERIALS AND METHODS}

Virus growth and purification: SFV (obtained from Dr. K. Hashimoto, NIH, Tokyo) has been plaque purified three times on $\mathrm{C} 3 \mathrm{H} / \mathrm{HeN}$ murine kidney cells. BHK cells were grown in Eagle's MEM supplemented with 6\% heat-inactivated calf serum in a 32-oz Roux flask. SFV was inoculated onto monolayers of the BHK cells at a multiplicity of $1 \mathrm{TCID}_{50}$ per cell. After cultivation at $37 \mathrm{C}$ for 24 
$\mathrm{hr}$, the culture supernatant was collected for preparation of virus particles. The concentrated virus suspension was layered onto a $10-40 \%(\mathrm{w} / \mathrm{w})$ linear sucrose gradient prepared in $50 \mathrm{ml}$ of TNE solution $(50 \mathrm{mM}$ Tris, $100 \mathrm{mM} \mathrm{NaCl}, 1 \mathrm{mM}$ EDTA, pH 7.2). The virus-layered gradient was centrifuged at 25,000 rpm for 100 min. The virus was collected and dialyzed against TNE solution for 12 to $16 \mathrm{hr}$. The purified virus preparation was stored at $-80 \mathrm{C}$ until use. SFV was inactivated by irradiation with ultraviolet at $1,600 \mathrm{erg} / \mathrm{cm}^{2}$ (UV-SFV) (12).

Preparation of viral proteins by sodium dodecyl sulfate (SDS)polyacrylamide gel electrophoresis $(P A G E)$ : Viral proteins were prepared by SDSPAGE (7.5\%) in the discontinuous system described by Laemmli (8). Gels were fixed, with coomassie brilliant blue, and destained with $10 \%$ acetic acid. The unstained gel corresponding to each viral protein band was cut and soaked in 50 $\mathrm{mM} \mathrm{NH}_{4} \mathrm{HCO}_{3}$ containing $0.1 \%$ SDS for $24 \mathrm{hr}$. After soaking and dialysis against TNE solution, it was used as a viral protein antigen (9).

Preparation of SFV-specific $T$ cells: Female $\mathrm{C} 3 \mathrm{H} / \mathrm{HeN}$ mice obtained from Japan Charles-River Co. (Atsugi, Japan) were injected subcutaneously into the footpads with $100 \mu \mathrm{g}$ of purified SFV incorporated in Freund's complete adjuvant (CFA). Ten days after immunization, $T$ were purified by passing the lymph node cell suspensions through a nylon column. The T cells $(4 \times 106$ cells $/ \mathrm{ml})$ were cultured in the presence of X-ray-irradiated syngeneic spleen cells as APC (3,000 $\mathrm{rad}, 2 \times 106 \mathrm{cells} / \mathrm{ml}$ ) and UV-SFV as antigens (10).

$S F V$-specific $T$-cell hybridomas: Cell-fusion was performed in vitro with the T cells, which had been subjected to secondary stimulation with UV-SFV in vitro and BW5147 tumor cells as described earlier $(10,11)$.

The hybrid cells generated in the culture in one or two weeks were picked, expanded, and tested for the antigen-induced production of IL-2. The hybrid cells showing SFV specificity were then cloned by limiting dilution.

Determination of the antigen-presenting ability of APC: The T-cell hybridomas $(5 \times 105$ cells) suspended in $0.1 \mathrm{ml}$ of the medium were distributed into each well of a 96-well microtiter plate, and then irradiated syngeneic spleen cells $\left(4 \times 10^{6}\right.$ cells $/ \mathrm{ml}$ ) as APC and UV-SFV antigen were added to each well. In some assays, the $\mathrm{C} 3 \mathrm{H} / \mathrm{HeN}$ murine spleen cells were treated with protease at the optimal concentration for $30 \mathrm{~min}$, or with $10 \mathrm{mM}$ of $\mathrm{NH}_{4} \mathrm{Cl}$ or monensin at various concentrations, and then cultured in the presence of UV-SFV at $37 \mathrm{C}$ for 2-3 $\mathrm{hr}$ without removing the inhibitor (12). The cells were washed exhaustively and used as APC. After cultivation of the T-cell hybridomas with APC and UVSFV antigen at $37 \mathrm{C}$ for $48 \mathrm{hr}$, the culture supernatant was collected and measured for its IL-2 level with CTLL-2 (an IL-2-dependent cell line). Stimulation of CTLL-2 cells was quantitated by the method of Mossman (13), with [3(4,5dimethylthiazol2yl)2,5 diphenyl tetrazolium bromide (MTT, Sigma, St. Louis, MO)]. The IL-2 concentration in the supernatant was calculated from 
the absorbance of the dye crystals produced by CTLL-2 cultured in known units of human recombinant IL-2.

Protease inhibitors and lysosomotropic agents: $10 \mathrm{mM}$ E64 [trans.epooxysuccinyl-L-leucyl-amido (4-guanidido) butane] (Sigma), $6 \mathrm{mM}$ leupeptin (Boehringer Mannheim Biochemicals, Inc., Tokyo), $10 \mathrm{mM}$ pepstatin (Sigma), $100 \mathrm{mM}$ of 1.10-phenanthroline (Sigma), $10 \mathrm{mM}$ monensin (Sigma), 10 mM TLCK (Sigma) and $10 \mathrm{mM} \mathrm{NH}_{4} \mathrm{Cl}$ were used as the storage chemicals (14).

In vitro digestion of $S F V$ proteins by treatment with cathepsin B: Purified $\mathrm{SFV}$ was dissolved in $0.07 \mathrm{M}$ citrate buffer at $\mathrm{pH} 5.0,6.0$, or 7.0. Cathepsin $\mathrm{B}$ (Sigma) added to these solutions at the final concentration of $1 \mu / \mathrm{ml}$ to allow reaction with SFV at $37 \mathrm{C}$ for $20 \mathrm{~min}$. The reaction mixtures were then analyzed by SDS-PAGE after addition of a protein lysis solution $(0.0625 \mathrm{M}$ Tris- $\mathrm{HCl}, 2 \%$ SDS, 5\% mercaptoethanol, 10\% glycerol and BPB) and subsequent boiling for 3 $\min$.

\section{RESULTS}

\section{Antigen Specificity of T-cell Hybridomas}

We attempted to obtain SFV-specific T-cell hybridomas from the draining lymph node cells of SFV-immunized mice and to determine the viral antigen specificity of each hybridoma. Eight hybridomas exhibited SFV-specific response. Six of them responded to the E2 protein purified by SDS-PAGE, while the remaining two clones consisted of one with specificity to the E1 protein and the other to C protein of SFV. Table I summarizes the antigen specificity of eight hybridomas. All of them were phenotyped as CD4+CD8- by cytofluorograph analysis (data not shown).

\section{Effects of Ammonium Chloride and Monensin on Antigen Presentation}

To clarify the process in which endocytosed SFV is digested in APC and processed as antigen, the effects of ammonium chloride and monensin on the antigen presentation by APC were studied. $\mathrm{C} 3 \mathrm{H}$ spleen cells were treated with either of these two agents for $2 \mathrm{hr}$ as described in Materials and Methods, and used as APC. The presentation of SFV antigen by the spleen cells to the SFVspecific AB4-2 T-cell hybridomas was suppressed by treatment of APC with ammonium chloride neutralizing the acidic compartments (Fig. 1). Monensin, a 


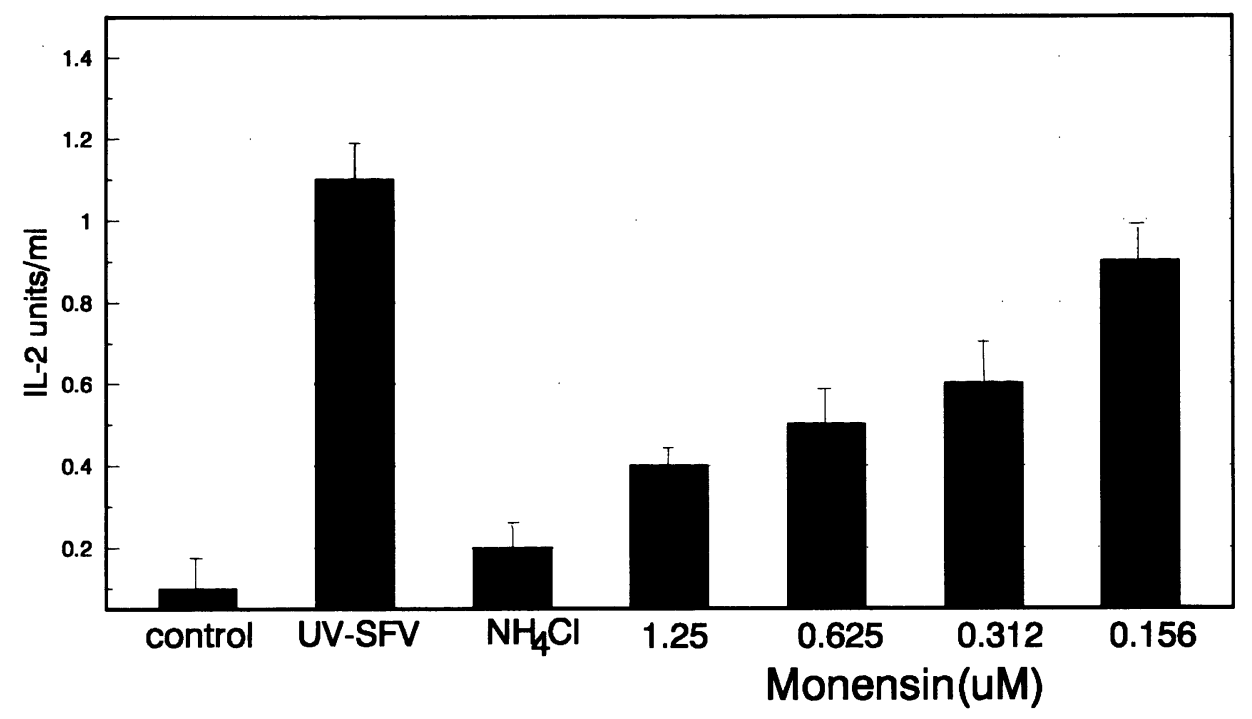

Fig. 1. Antigen-presenting ability of spleen cells treated with ammonium chloride or monensin.

AC3H murine spleen cells were treated for 30 min with $10 \mathrm{mM}$ ammonium chloride or monensin at the concentration shown in the figure, added with 108 TCID $_{50}$ of UV-SFV, and cultured for $2 \mathrm{hr}$. The spleen cells were washed, added with the AB4-2 T-cell hybridomas, and cultured for $48 \mathrm{hr}$. After culturing, the supernatant was harvested and the IL-2 activities contained therein were measured with CTLL-2 cells (IL-2 dependent cells). The IL-2 activity was calculated from the absorbance of human recombinant IL-2.

carboxylic ionophore also inhibited APC from presenting SFV antigens to AB4-2 T-cell hybridomas.

\section{Effects of Protease Inhibitors on Antigen Presentation}

The effects of endopeptidase inhibitors on antigen presentation were studied. APC treated with leupeptin, a thiol- and serine-protease inhibitor, were inhibited in the ability to present UV-SFV antigen to E2 protein-specific AB4-2 T-cell hybridomas. By contrast, the ability of the treated APC to present the antigen to $\mathrm{E} 2$ protein-specific AB8-2 T-cell hybridomas was increased. The ability of the treated APC to present the antigen to E2 protein-specific BF12-2 and AB9-2 T-cell hybridomas was not affected (Table II). To determine which of the two endopeptidases, thiol or serine protease, works in antigen processing of 
Table I. IL-2 production by T-cell hybridomas in response to Semliki forest virus structual proteins

\begin{tabular}{lrrrc}
\hline \multirow{2}{*}{ T-cell hybridoma } & \multicolumn{3}{c}{ IL-2 units/ml } & \multirow{2}{*}{ Specificity } \\
\cline { 2 - 4 } & \multicolumn{1}{c}{ E2 } & E1 & \multicolumn{1}{c}{ C } & \\
\hline AB9-2 & 2.30 & 0.28 & 0.10 & E2 \\
BF12-2 & 10.40 & 0.25 & 0.06 & E2 \\
AB8-2 & 21.78 & 0.03 & 0.03 & E2 \\
AD5-1 & 25.06 & 0.40 & 0.41 & E2 \\
AB4-2 & 16.57 & 0.03 & 0.03 & E2 \\
AB2-3 & 17.96 & 0.03 & 0.03 & E2 \\
AF7-2 & 0.03 & 0.03 & 12.63 & C \\
AD9-1 & 0.03 & 22.86 & 0.03 & E1 \\
\hline
\end{tabular}

T-cell hybridomas were tested with Semliki forest virus structual protein eluted from SDS-PAGE and irradiated spleen cells $(4 \times 105)$. In 2 days, supernatants were tested for IL- 2 by CTLL- 2 assay.

Table II. Differential effects of leupeptin on presentation of Semliki forest virus

\begin{tabular}{crrrc}
\hline T-cell hybridomas & \multicolumn{4}{c}{ IL-2 units/ml } \\
\cline { 2 - 5 } Treatment & AB4-2 & AB8-2 & AB9-2 & BF12-2 \\
\hline Control & $<0.1$ & $<0.1$ & $<0.1$ & $<0.1$ \\
UV-SFV & 6.8 & 22.5 & 18.5 & 19.6 \\
$+0.75 \mathrm{mM}$ & & & & \\
$\begin{array}{c}\text { leupeptin } \\
+1.5 \mathrm{mM}\end{array}$ & 2.6 & 76.9 & 20.1 & 18.9 \\
leupeptin & 1.6 & 61.5 & 19.6 & 25.9 \\
\hline
\end{tabular}

C3H mice spleen cells were treated with the indicated leupeptin for 30 min, then incubated (without removal of inhibitor) with UV-irradiated SFV for $2 \mathrm{hr}$ at $30 \mathrm{C}$. After incubation, these spleen cells were irradiated with $3000 \mathrm{rad}$ and washed with RPMI 1640 three times. The treated spleen cells were cultured with each T-cell hybridoma for 2 days in the absence of antigen. The results are shown as mean values of triplicate assay. 


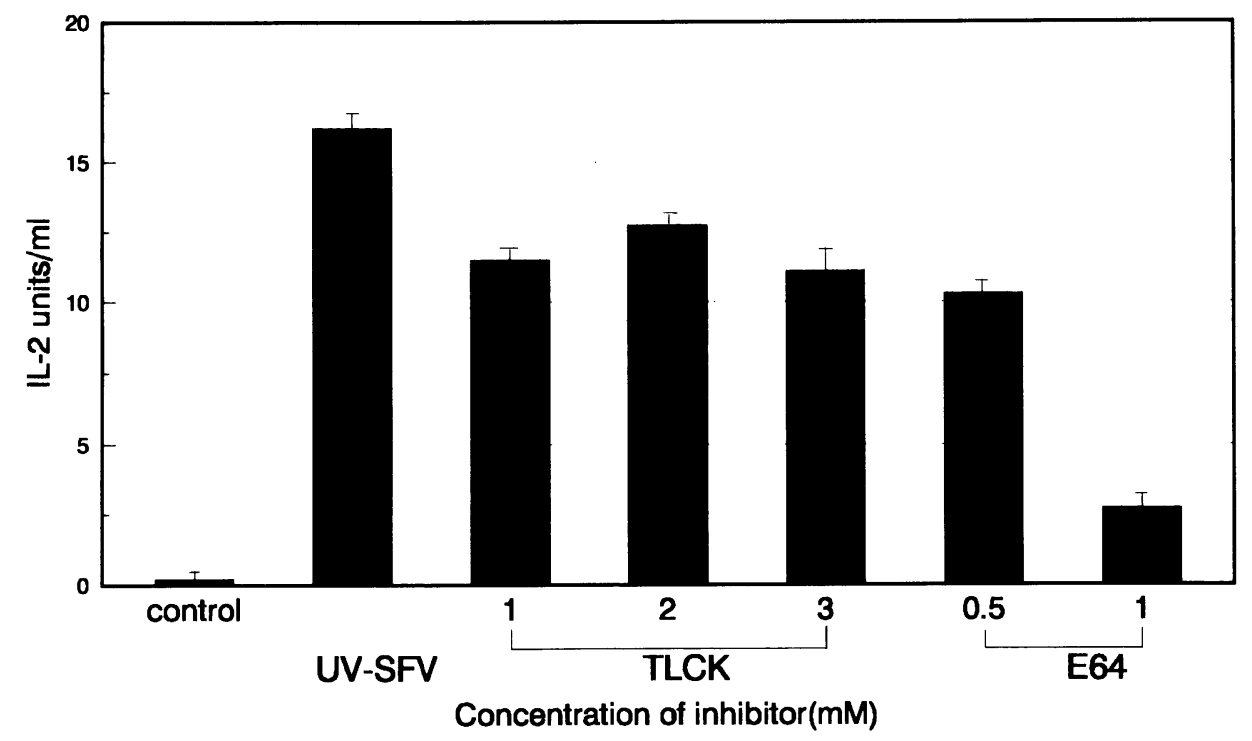

Fig. 2. Antigen-presenting ability of spleen cells treated with a thiol and serine protease inhibitor.

C3H murine spleen cells were treated for $30 \mathrm{~min}$ with a protease inhibitor (E64 or TLCK), added with 108 TCID $_{50}$ of UV-SFV, and cultured for $2 \mathrm{hr}$. The spleen cells were washed, added with AB4-2 Tcell hybridomas, and cultured for $48 \mathrm{hr}$. After culturing, the supernatant was harvested and the IL-2 activities contained therein were measured with CTLL-2 cells (IL-2 dependent cells). The IL-2 activity was calculated from the absorbance of human recombinant IL2.

APC for the presentation of E2 to AB4-2 T-cell hybridomas, spleen cells were treated with E64. E64 is known to suppress the action of thiol such a protease as cathepsin B. The treatment was found to suppress the presentation of SFV antigen to E2 protein-specific AB4-2 T-cell hybridomas (Fig. 2). Treatment of spleen cells with TLCK slightly suppressed the presentation of SFV antigen to AB4-2 T-cell hybridomas. Treatment of APC with pepstatin (0.025-0.1 mM) or 1.10-phenanthroline, an acidic or metallic protease inhibitor, showed no effect on the presentation of SFV antigen to AB4-2 T-cell hybridomas (Fig. 3).

These results suggest that the presentation of SFV antigen to SFV E2 protein-specific AB4-2 T-cell hybridomas requires the antigen processing of UVSFV by thiol such a protease as cathepsin $B$. 


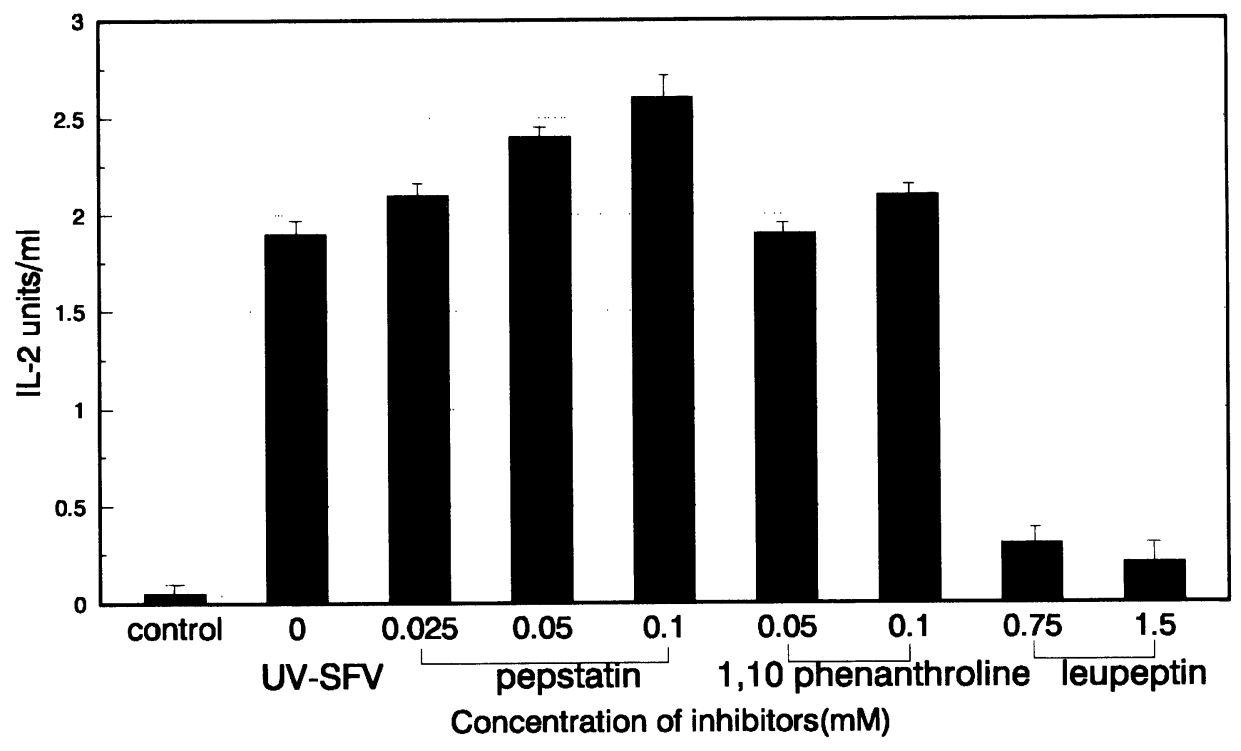

Fig. 3. Antigen-presenting ability of spleen cells treated with an acidic or metallic protease inhibitor.

C3H murine spleen cells were treated for $30 \mathrm{~min}$ with a protease inhibitor (pepstatin or 1-10 phenanthrolin), added with 108 TCID $_{50}$ of UV-SFV, and cultured for $2 \mathrm{hr}$. The spleen cells were washed, added with the AB4-2 hybridomas, and cultured for $48 \mathrm{hr}$. After culturing, the supernatant was harvested and the IL-2 activities contained therein were measured with CTLL-2 cells (IL-2 dependent cells). The IL-2 activity was calculated from the absorbance of human recombinant IL-2.

\section{Differences among E1,E2 and C Proteins of SFVin Sensitivity to Cathepsin B}

To determine the sensitivities of SFV-proteins E2, E1, and C to cathepsin B at different $\mathrm{pH}$ values, purified SFV samples were first subjected to dialysis overnight at $4 \mathrm{C}$ against the buffer at different $\mathrm{pH}$ values, 5.0,6.0, and 7.0. The dialyzed SFV samples were treated with cathepsin B in the presence of cysteine$\mathrm{HCl}$ at $37 \mathrm{C}$ for $20 \mathrm{~min}$ and then subjected to SDS-PAGE 7.5\% gel, as described in Materials and Methods. As shown in Fig. 4, the protein band corresponding to E2 protein disappeared in the SFV sample treated with cathepsin B at $\mathrm{pH} 5.0$, while those corresponding to $\mathrm{E} 1$ and $\mathrm{C}$ proteins remained intact (lane $\mathrm{C}$ ). The bands of 


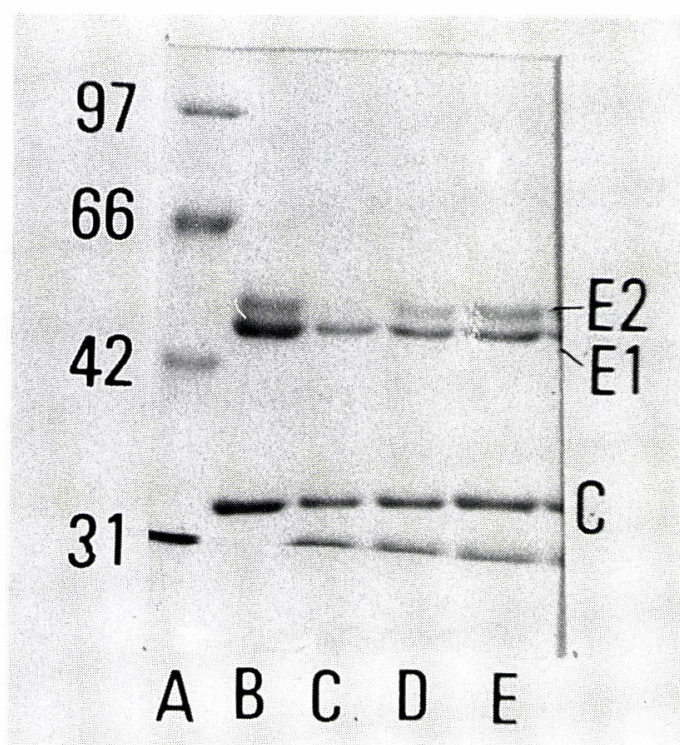

Fig. 4. Change in SFV structual protein on treatment with cathepsin B.

SFV dialyzed against a citric acid buffer solution at $\mathrm{pH} 5.0,6.0$ or 7.0 was treated wiht $1 \mu / \mathrm{ml}$ of cathepsin B at $37 \mathrm{C}$ for $20 \mathrm{~min}$. After solubilization in an SDS-containing solution under reducing conditions, SDS-PAGE (7.5\%) was carried out. A shows the molecule marker, B the SFV preparation, $C$ the sample obtained by enzymatic digestion for $20 \mathrm{~min}$ at $\mathrm{pH} 5.0, \mathrm{D}$ that at $\mathrm{pH} 6.0$, and $\mathrm{E}$ that at $\mathrm{pH} 7.0$.

SFV samples treated with cathepsin B at pH 6.0 (lane D) or pH 7.0 (lane E) were clearly visible as those of the untreated sample (lane B). E2 protein was partially digested at $\mathrm{pH} 6.0$, as revealed by the faint band, when treatment with cathepsin $\mathrm{B}$ was prolonged to $120 \mathrm{~min}$ (data not shown). These results indicate that E2 protein of SFV is sensitive to cathepsin $\mathrm{B}$ at $\mathrm{pH} 5.0$ and 6.0, while E1 and C proteins are not even at $\mathrm{pH}$ 5.0.

\section{DISCUSSION}

To clarify the mechanism of the preferential stimulation of SFV-immunized mice by E2, we, using C3H spleen cells immunized with UV-SFV, prepared SFVspecific T-cell hybridomas. The present study has demosntrated that six of eight SFV-specific T-cell hybridomas were capable of recognizing primarily the viral 
trans-membrane glycoprotein E2 and only two hybridomas recognized other membrane proteins $\mathrm{E} 1$ and $\mathrm{C}$. We found before that spleen cells prepared from both the $\mathrm{BALB} / \mathrm{c}$ and $\mathrm{C} 3 \mathrm{H} / \mathrm{HeN}$ mice immunized with UV-SFV were activated with $\mathrm{E} 2$ protein more strongly than with $\mathrm{E} 1$ or $\mathrm{C}$ proteins (data not shown). These results demonstrated that the present findings are true in not only $\mathrm{C} 3 \mathrm{H} / \mathrm{HeN}$ but also BALB/c mice.

Such lysosomotropic agents as ammonium chloride and chloroquin have been reported to suppress the antigen-presenting ability as a result of their raising the $\mathrm{pH}$ value in the acidic compartments $(15,16)$. From these findings, the suppression of the antigen presentation in our experiments may have been caused by the increased in $\mathrm{pH}$ value in the acidic compartments of spleen cells as a result of ammonium chloride treatment. Monensin suppressed the presentation of E2 protein to AB4-2 T-cell hybridomas (Fig. 1). It has been reported that monensin inhibits the intracellular transport of antigen through endosomes and Golgi apparatus (14) and also the antigen presentation by neutralizing acidic vesicles in APC as a lysosomotropic agent (17). It is not clear which function of monensin is working for the inhibition of SFV antigen presentation.

The sensitivity of the protein to protease greatly affects the antigen processing. Leupeptin is a tripeptide competitively inhibiting thiol and serine proteases in the acidic compartments (18). The study showed that treating with leupeptin leads to a suppression of the antigen presention to AB4-2 T-cell hybridomas, but to an augmentation of the presentation to AB8-2 T-cell hybridomas (Table II). The protease present in the acidic compartments is known to have two opposite functions, one increases immunogenicity by digesting the protein antigen and the other decreases immunogenicity (19). The finding that the thiol protease activity is reduced on addition of leupeptin may be interpreted in the sense that the resulting antigen fragment in the antigen-presenting cell is not appropriate for its presentation as an antigen on AB4-2 T-cell hybridomas, but is a more effective fragment for presentation on AB8-2 T-cell hybridomas. This is substantiated by the fact that the response of AB4-2 T-cell hybridomas is inhibited on addition of a thiol protease inhibitor, E64 (Fig. 3). It is therefore conceivable that AB4-2 T-cell hybridomas have a specific ability to recognize the peptide that is digested by such a thiol protease as cathepsin B in the acidic compartments. We did not succeed, however, in the activation of AB4-2 T-cell hybridomas by APC pulsed in vitro with the cathepsin B-digested SFV peptides, probably because the concentrations of the peptides used in our experiments were lower than the levels necessary to elicit the desired responses. Eisenlohr et al. 
(20) reported that the concentration of antigen necessary for the activation of hybridomas is higher for virus peptide than for whole virus.

Cathepsin B is known to be present in the acidic compartments. E2 protein was resistant against in vitro treatment of SFV for $20 \mathrm{~min}$ at $\mathrm{pH} 6.0$ with cathepsin $\mathrm{B}$ but sensitive to it at $\mathrm{pH}$ 5.0. $\mathrm{E} 1$ and $\mathrm{C}$ protein, were resistant to digestion at either $\mathrm{pH}$. The early endosome has $\mathrm{pH}$ of $6.5-6.2$, the sorting endosome $\mathrm{pH}$ of 6.2 or lower, the late endosome $\mathrm{pH}$ of 5.2-5.8, and the lysosome $\mathrm{pH}$ of 4.65 or lower $(1,21)$. Cathepsin $\mathrm{B}$ and $\mathrm{D}$ are primarily localized in the Iapositive late endosome (22). This means that APC cannot present the SFV antigen on the AB4-2 hybridomas unless the viral proteins have previously been digested by a thiol protease in the late endosome.

\section{ACKNOWLEDGEMENTS}

We thank Dr. Katsuyuki Hashimoto and Dr. Kiichi Yamamoto (NIH, Tokyo) for the gift of SFV. The authors wish to express their gratitude to Dr. Hidemi Takahashi, Mr. Yoshihiko Norose and Mrs. Yoko Nakagawa for their frequent, stimulating, and helpful discussions.

\section{RREFERENCES}

1. Koblet, H. (1990): The "merry-go-round": Alphaviruses between vertebrate and invertebrate. Adv. Virus Res., 38, 343-402.

2. Ashman, R. B. and Mullbacher, A. (1979): A T helper cell for antiviral cytotoxic T cell response. J. Exptl. Med., 150, 1277-1282.

3. Babbitt, B. P., Allen, P. M., Matsueda, G., Haber, E. and Unanue, E. R. (1985): Binding of immunogenic peptides to Ia histocompatibility molecules. Nature, 317, 359-361.

4. Kielian, M., Jungerwirth, S., Sayad, K. U. and Decasndido, S. (1990): Biosynthesis, maturation, and activation of the Semliki forest virus fusion protein. J. Virol, 64, 4614-4624.

5. Kielian, M. and Helenius, A. (1985): pH-Induced alterations in the fusogenic spike protein of Semliki Forest virus. J. Cell Biol., 101, 22842291. 
6. Omar, A. and Koblet, H. (1988): Semliki forest virus particles containing only the $\mathrm{E} 1$ envelope glycoprotein are infectious and can induce cell-cell fusion. Virology, 166, 17-23.

7. Kraảijeveld, C. A., Harmsen, M. and Khader, B. (1979): Delayed type hypersensitivity against Semlike Forest Virus in mice. Infect. Immun., 23, 219-223.

8. Laemmli, U. K. (1970): Cleavage of structural proteins during the assembly of the head of bacteriophage T4. Nature, 227, 680-685.

9. Hunkaapiller, M. W., Lujan, E., Ostrander, F. and Hood, L. E. (1983): Isolation of microgram quantities of proteins from polyacrylamide gels for amino acid sequence analysis. In $\mathrm{C}$. H. W. Hirs and S. N. Timasheff (eds.), Methods in Enzymology, Vol. 91, 227-236. Academic Press, New York.

10. Hurwitz, J. I., Heber-Katz, E., Hacket, J. C. and Gerhard, W. (1984): Characterization of the murine $\mathrm{Th}$ response to influenza virus hemagglutinin: Evidence for three major specificities. J. Immunol., 133, 3371-3377.

11. Heber-Katz, E., Valentine, S., Dietzshold, B. and Burnspurzycki, C. (1988): Overlapping $\mathrm{T}$ cell antigenic sites on a synthetic peptide fragment from herpes simplex virus glycoprotein $\mathrm{D}$, the degenerate $\mathrm{MHC}$ restriction elicited, and function evidence for antigen Ia interaction. J. Exptl. Med., 167, 275-287.

12. Morrison, L. A., Lukacher, A. E., Braciale, V. L., Fan, D. P. and Braciale, T. J. (1986): Differences in antigen presentation to MHC class I and II restricted influenza virus specific cytotoxic T lymphocyte clones. J. Exptl. Med., 163, 903-921.

13. Mossman, T. R. (1983): A rapid colorimetoric assay for cellular growth and survival: application to proliferation and cytotoxic assays. J. Immunol. Meth., 65, 55-63.

14. Takahashi, H., Cease, K. B. and Berzofsky, J. A. (1989): Identification of proteases that process distinct epitopes on the same protein. J. Immunol., 142, 2212-2229.

15. Superti, F., Segasnti, U., Ruggeri, F. M., Tinari, A., Donelli, G. and Orsi, N. (1987): Entry pathway of vesicular stomatitis virus into different host cells. J. Gen. Virol., 68, 387-399.

16. Ziegler, H. K. and Unanue, E. R. (1982): Decrease in macrophage antigen catabolism caused by ammonia and chloroquin in associated with inhibition of antigen presentation to T cells. Proc. Natl. Acad. Sci. U.S.A., 79, 175-178.

17. Diment, S. (1990): Differnet roles for thiol and aspartyl proteases in antigen presentation of ovalbumin. J. Immunol., 145, 417-422.

18. Aoyagi, T. and Umezawa, H. (1975): Structure and activities of protease inhibitors of microbial origin. p.429. In E. Reich, B. Rifkins and E. Shaw (eds.), Proteases and Biological Control, Vol. 2, Cold Spring Harbor, New York. 
19. Vidard, L., Rock, K. L. and Benaceraf, B. (1991): The generation of immunogenic peptides can selectively increase or decrease by proteolytic enzyme inhibitors. J. Immunol., 147, 1786-1791.

20. Eisenlohr, L. C., Gerhard, W. and Hackett, C. J. (1987): Role of receptorbinding activity of the viral hemagglutinin molecule in the presentation Influenza virus antigens to helper T cells. J. Virol., 61, 1375-1383.

21. Mellman, I., Fuchs, R. and Helenius, H. (1986): Acidification of the endocytic and exocytic pathways. Annu. Rev. Biochem., 55, 663-700.

22. Lang, T. and Antonie, J. C. (1991): Localization of MHC Class II molecules in murine bone marrow derived macrophages. Immunology, 72, 199-205. 